\title{
Article \\ Inhibitory Effects of Sulfonamide Derivatives on the $\beta$-Carbonic Anhydrase (MpaCA) from Malassezia pachydermatis, a Commensal, Pathogenic Fungus Present in Domestic Animals
}

\author{
Viviana De Luca ${ }^{1,2,+}$, Andrea Angeli ${ }^{3,+}+\mathbb{0}$, Valeria Mazzone ${ }^{1}$, Claudia Adelfio ${ }^{1}$, Fabrizio Carta ${ }^{3}(\mathbb{D}$,

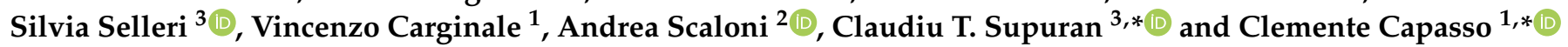 \\ 1 Institute of Biosciences and Bioresources, CNR, Via Pietro Castellino 111, 80131 Napoli, Italy; \\ viviana.deluca@ibbr.cnr.it (V.D.L.); valeria.mazzone@ibbr.cnr.it (V.M.); cla.delfio@gmail.com (C.A.); \\ vincenzo.carginale@ibbr.cnr.it (V.C.) \\ 2 Proteomics, Metabolomics \& Mass Spectrometry Laboratory, Institute for the Animal Production System in \\ the Mediterranean Environment, CNR, P.le Enrico Fermi 1, 80055 Portici (Napoli), Italy; \\ andrea.scaloni@ispaam.cnr.it \\ 3 Section of Pharmaceutical and Nutraceutical Sciences, Department of Neurofarba, University of Florence, \\ Via U. Schiff 6, 50019 Sesto Fiorentino (Florence), Italy; andrea.angeli@unifi.it (A.A.); \\ fabrizio.carta@unifi.it (F.C.); silvia.selleri@unifi.it (S.S.) \\ * Correspondence: claudiu.supuran@unifi.it (C.T.S.); clemente.capasso@ibbr.cnr.it (C.C.); \\ Tel.: +39-055-4573729 (C.T.S.); +39-081-613-2559 (C.C.) \\ check for \\ updates \\ + These authors equally contributed to this work.
}

Citation: De Luca, V.; Angeli, A.; Mazzone, V.; Adelfio, C.; Carta, F.; Selleri, S.; Carginale, V.; Scaloni, A.; Supuran, C.T.; Capasso, C. Inhibitory Effects of Sulfonamide Derivatives on the $\beta$-Carbonic Anhydrase (MpaCA) from Malassezia pachydermatis, a Commensal, Pathogenic Fungus Present in Domestic Animals. Int. J. Mol. Sci. 2021, 22, 12601. https:// doi.org/10.3390/ijms222212601

Academic Editor: Fabio Altieri

Received: 28 October 2021

Accepted: 19 November 2021

Published: 22 November 2021

Publisher's Note: MDPI stays neutral with regard to jurisdictional claims in published maps and institutional affiliations.

Copyright: (c) 2021 by the authors. Licensee MDPI, Basel, Switzerland. This article is an open access article distributed under the terms and conditions of the Creative Commons Attribution (CC BY) license (https:/ / creativecommons.org/licenses/by/ $4.0 /)$.

\begin{abstract}
Fungi are exposed to various environmental variables during their life cycle, including changes in $\mathrm{CO}_{2}$ concentration. $\mathrm{CO}_{2}$ has the potential to act as an activator of several cell signaling pathways. In fungi, the sensing of $\mathrm{CO}_{2}$ triggers cell differentiation and the biosynthesis of proteins involved in the metabolism and pathogenicity of these microorganisms. The molecular machineries involved in $\mathrm{CO}_{2}$ sensing constitute a promising target for the development of antifungals. Carbonic anhydrases (CAs, EC 4.2.1.1) are crucial enzymes in the $\mathrm{CO}_{2}$ sensing systems of fungi, because they catalyze the reversible hydration of $\mathrm{CO}_{2}$ to proton and $\mathrm{HCO}_{3}{ }^{-}$. Bicarbonate in turn boots a cascade of reactions triggering fungal pathogenicity and metabolism. Accordingly, CAs affect microorganism proliferation and may represent a potential therapeutic target against fungal infection. Here, the inhibition of the unique $\beta$-CA (MpaCA) encoded in the genome of Malassezia pachydermatis, a fungus with substantial relevance in veterinary and medical sciences, was investigated using a series of conventional CA inhibitors (CAIs), namely aromatic and heterocyclic sulfonamides. This study aimed to describe novel candidates that can kill this harmful fungus by inhibiting their CA, and thus lead to effective anti-dandruff and anti-seborrheic dermatitis agents. In this context, current antifungal compounds, such as the azoles and their derivatives, have been demonstrated to induce the selection of resistant fungal strains and lose therapeutic efficacy, which might be restored by the concomitant use of alternative compounds, such as the fungal CA inhibitors.
\end{abstract}

Keywords: carbonic anhydrase; Malassezia pachydermatis; $\mathrm{CO}_{2}$ sensing; sulfonamide inhibitors; anti-dandruff; antifungals

\section{Introduction}

Carbon dioxide $\left(\mathrm{CO}_{2}\right)$ is ubiquitously generated and released into the atmosphere through cellular respiration and oxidative metabolism [1]. This gas byproduct is typically transported out of cells via passive diffusion. This transport may be aided by $\mathrm{CO}_{2}$ channels, which are regulated in a $\mathrm{CO}_{2}$-dependent way [2,3]. Rather than a waste product, $\mathrm{CO}_{2}$ has also the potential to act as a physiological stimulant for a variety of cellular signaling pathways that promote microorganism virulence and pathogenicity $[1,3,4]$. For example, 
Bacteria assist their colonization and infection at $\mathrm{CO}_{2}$ concentration levels comparable to those found in the host, since bacterial $\mathrm{CO}_{2}$ sensing mechanisms allow them to adapt and survive in such environments [1]. During their life cycle, fungi are exposed to various environmental variables, including fluctuations in $\mathrm{CO}_{2}$ levels [1]. Dedicated $\mathrm{CO}_{2}$ sensing machineries allow fungi to sense the amount of $\mathrm{CO}_{2}$ present in mammalian tissues (about $5 \%$ ), compared to the atmospheric levels (about $0.03 \%$ ), which ultimately stimulates the fungal pathogenicity in the host $[1,4]$.

In microorganisms, proteins involved in sensing $\mathrm{CO}_{2}$ have been suggested as attractive targets of pharmaceuticals since they modulate cell differentiation and the further production of molecules essential for the pathogen $[4,5]$. In this context, it has been demonstrated that carbonic anhydrases (CAs, EC 4.2.1.1), catalyzing the reversible hydration of $\mathrm{CO}_{2}$ to $\mathrm{HCO}_{3}{ }^{-}$and $\mathrm{H}^{+}\left(\mathrm{CO}_{2}+\mathrm{H}_{2} \mathrm{O} \rightleftharpoons \mathrm{HCO}_{3}{ }^{-}+\mathrm{H}^{+}\right)$[6-12], are crucial enzymes in fungal $\mathrm{CO}_{2}$ sensing since they produce bicarbonate, which is a promoter (through an adenylate cyclase (AC) intermediate enzyme) of fungal meiosis and sporulation [13]. Indeed, $\mathrm{HCO}_{3}{ }^{-}$ produced in a CA-dependent manner activates AC and cyclic adenosine monophosphate (cAMP) production, which stimulates the development of filamentous structures (hyphae) needed for fungal virulence, adhesion, and the production of hydrolases, thus triggering cell death in the colonized host $[4,5,14,15]$. Up to date, eight CA gene families or classes have been identified and designated with Greek letters $(\alpha, \beta, \gamma, \delta, \zeta, \eta, \theta, \iota)[6-10]$. In the fungal kingdom, the typical class is represented by $\beta$-CAs, which generally occur with at least one isoform. Conversely, $\alpha$-CAs are rarely found in fungi [5,16-18]. The catalytic action of fungal CAs triggers a cascade process, which allows the microorganism to adapt into the host, thrive therein, and contribute to its pathogenicity $[4,14,15,18,19]$. It is readily apparent that CAs can affect fungal growth and thus may represent a potential novel therapeutic target in fungal infections. This is corroborated by the studies of Supuran's group, who demonstrated that typical CA inhibitors (CAIs), namely primary sulfonamides, inhibit the growth of Malassezia globosa when $\mathrm{CO}_{2}$ availability is limited (i.e., fungus-infected skin surface) [20]. In this context, we have focalized our interest on another such fungus, M. pachydermatis, which has a significant relevance in veterinary and medical sciences, as it has been associated with otitis externa and seborrheic dermatitis in dogs, cats, and wild animals, as well as with fungemia in hospitalized and immunocompromised patients [21-24]. When the skin microenvironment or the host's defenses are compromised, this opportunistic commensal has the potential to become a disease-causing pathogen [21,22]. In this context, we determined that the genome of the M. pachydermatis contains a single gene encoding a $\beta$-CA (acronym $\mathrm{MpaCA}$ ) that is closely related to $\beta$-CAs previously identified by our groups in two other Malassezia species, namely M. globosa and $M$. restricta, which are responsible for dandruff and seborrheic dermatitis [20,25-34].

Here, we have further investigated $\mathrm{MpaCA}$, focusing on its inhibition profile with respect to a series of aromatic or heterocyclic sulfonamides, which are widely used as building blocks for obtaining potent and selective pharmacological agents. Besides, inhibition data on MpaCA have been compared with those of ortholog $\beta$-CA enzymes from M. globosa and $M$. restricta, namely $\mathrm{MgCA}$ and MreCA, respectively. Overall, this study tentatively proposes novel potential anti-dandruff and anti-seborrheic dermatitis compounds able to eradicate harmful fungi through the inhibition of CAs. This is potentially relevant since clinically used antifungal drugs, such as azoles and their derivatives, as result of their widespread diffusion, have determined the selection of resistant fungal strains.

\section{Results and Discussion}

\subsection{Biochemical Characterization of $\mathrm{MpaCA}$}

Recombinant M. pachydermatis CA (MpaCA) was overexpressed in E. coli as a fusion protein with a non-natural tail containing six histidines at its molecular $\mathrm{N}$-terminus, and purified by affinity chromatography. The purified enzyme was then subjected to SDSPAGE and protonography to certify the corresponding molecular mass and ability to elicit a hydratase activity. As shown in Figure 1, SDS-PAGE demonstrated that recombinant 
MpCA was recovered in the soluble fraction of the bacterial extract in response (after $3 \mathrm{~h}$ ) to isopropyl- $\beta$-D-thiogalactopyranoside (IPTG) induction. Recombinant MpCA showed an experimental molecular mass of about $30 \mathrm{kDa}$, in agreement with the expected theoretical one $(31 \mathrm{kDa})$.

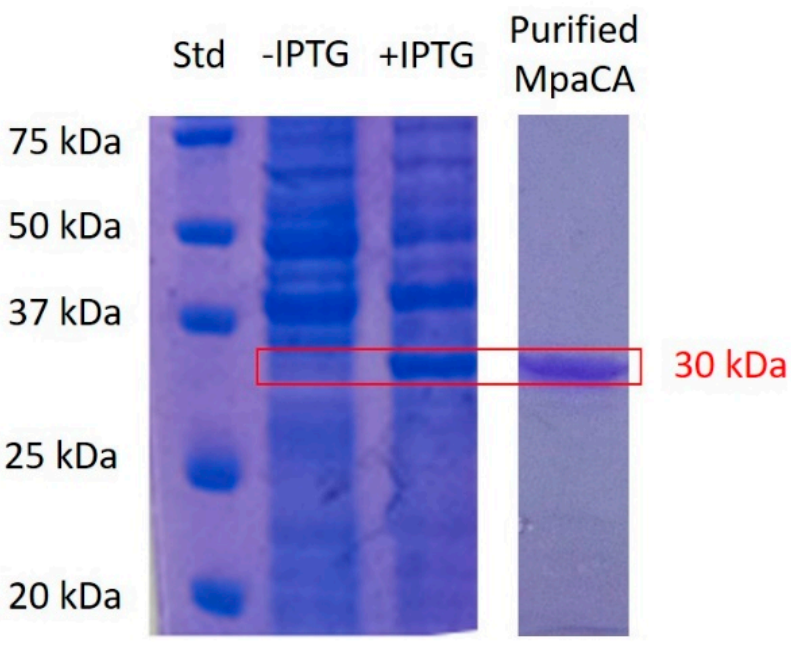

Figure 1. SDS-PAGE showing results regarding MpaCA heterologous expression in bacterial cells and further purification from corresponding extracts. A total of $1 \mathrm{mM}$ IPTG was used to induce MpaCA biosynthesis. Overexpressed MpaCA is visible in the lane indicated with "+IPTG", migrating with an apparent molecular mass of about $30 \mathrm{kDa}$. The enzyme is not present in lane "-IPTG", which shows the bacterial lysate supernatant before isopropyl- $\beta$-D-thiogalactopyranoside induction. A bacterial extract containing soluble MpaCA was resolved on a HisTrap FF column to yield a pure, homogeneous preparation of the fungal enzyme (Lane "Purified MpaCA"). The red box represents MpaCA migrating with an experimental molecular mass of $30 \mathrm{kDa}$.

Protonographic analysis (Figure 2) was used to determine whether purified recombinant $\mathrm{MpaCA}$ could catalyze the $\mathrm{CO}_{2}$ hydration reaction (Figures 1 and 2). Two homologous CAs, namely MgCA and MreCA, which are encoded from the genome of M. globosa and $M$. restricta, respectively, were used as positive controls. As expected, the protonogram in all cases exhibited yellow bands migrating at a molecular mass of about $30 \mathrm{kDa}$ (Figure 2), thus demonstrating a $\mathrm{CO}_{2}$ hydratase activity for all fungal CAs, including MpaCA.

\section{Std MreCA MgCA MpaCA}

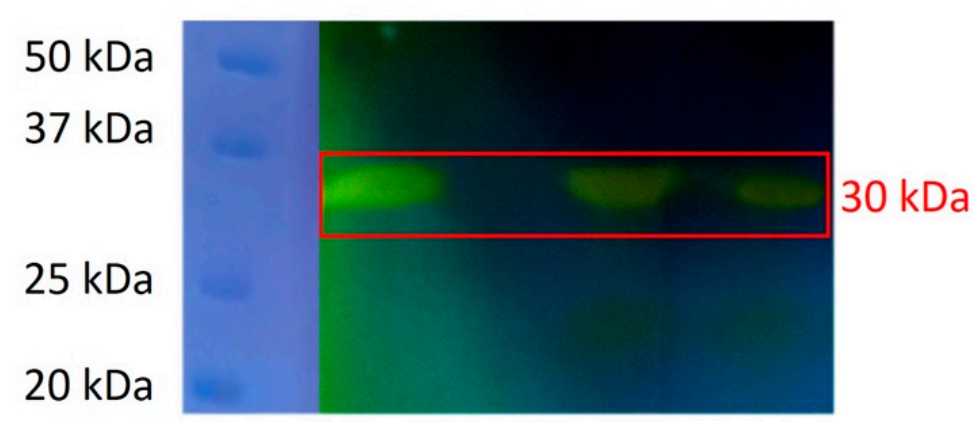

Figure 2. Protonographic analysis of $\mathrm{MreCA}, \mathrm{MgCA}$, and $\mathrm{MpaCA}$. The $\mathrm{CO}_{2}$ hydratase activity was directly evaluated on the polyacrylamide gel through the development of yellow bands due to $\mathrm{pH}$ value variations (acidic $\mathrm{pH}$ ) resulting from the conversion of $\mathrm{CO}_{2}$ to bicarbonate and protons $\left(\mathrm{H}^{+}\right)$. Legend: Lane Std, molecular markers; Lane MreCA, purified MreCA; Lane MgCA, purified MgCA; Lane MpaCA, purified MpaCA. The red box shows the enzyme activity of the three fungal enzymes, which migrated with an apparent molecular mass of about $30 \mathrm{kDa}$. 
With the aid of the stopped-flow technique, we further demonstrated that MpaCA exhibits an appreciable $\mathrm{CO}_{2}$ hydrase activity, with a $\mathrm{k}_{\mathrm{cat}}$ value of $3.8 \times 10^{5} \mathrm{~s}^{-1}$ and $\mathrm{k}_{\mathrm{cat}} / \mathrm{K}_{\mathrm{M}}$ value of $9.7 \times 10^{6} \mathrm{M}^{-1} \mathrm{~s}^{-}$. MgCA and MreCA showed a catalytic activity very similar to that of MpaCA. In particular, MreCA showed a $\mathrm{k}_{\text {cat }}$ value $=1.06 \times 10^{6} \mathrm{~s}^{-1}$ and $\mathrm{k}_{\mathrm{cat}} / \mathrm{K}_{\mathrm{M}}$ value $=1.07 \times 10^{8} \mathrm{M}^{-1} \mathrm{~s}^{-1}$ [25], while MgCA exhibited a $\mathrm{k}_{\text {cat }}$ value of $9.2 \times 10^{5} \mathrm{~s}^{-1}$ and $\mathrm{k}_{\text {cat }} / \mathrm{K}_{\mathrm{M}}$ value of $8.3 \times 10^{7} \mathrm{M}^{-1} \mathrm{~s}^{-1}$ [27-33].

\subsection{Inhibition Profile of $\mathrm{MpaCA}$ with Sulfonamides}

Sulfonamide compounds represent a significant class of synthetic bacteriostatic antibiotics still used today to treat infections caused by bacteria and other microorganisms [35-37]. They are also known as sulfa drugs. These compounds are derived from sulfanilamide (compound A in Figure 3) and include synthetic derivatives with the general chemical structure B [38]. Worth mentioning is the fact that often the term sulfonamide is imprecisely referred to antibiotics bearing a sulfonamide moiety, and not all sulfonamides are antibiotics [39]. Sulfonamide antibiotics have two structural characteristics that distinguish them from nonantibiotic counterparts, namely a free amino group at N4 and a nitrogen-containing heterocyclic ring linked to N1 of the sulfonamide group (compounds B) (Figure 3). Furthermore, the discovery that sulfanilamide A has CA inhibitory properties [40] led to the discovery that corresponding derivatives $C$ act as effective enzyme inhibitors (Figure 3) [41]. The above-mentioned structural features are essential in mediating allergic reactions to sulfonamide antibiotics [39]. A growing body of clinical evidence indicates no increased risk of reactions to nonantibiotic sulfonamides in patients with a history of allergy to sulfonamide antibiotics [39].<smiles>Nc1ccc(S(N)(=O)=O)cc1</smiles>

A<smiles>[R]NOS(=O)(=O)c1ccc(N)cc1</smiles>

B<smiles>[R]Nc1ccc(S(N)(=O)=O)cc1</smiles>

C

Figure 3. Sulfanilamide (Panel A) led to the discovery of the sulfadrugs (Panel B) and benzenesulfonamide CAIs of type (Panel C).

Among nonantibiotic sulfonamides, primary sulfonamides $\left(\mathrm{R}^{\prime}-\mathrm{SO}_{2}-\mathrm{NH}_{2}\right)$ showed the most promising results due to their $\mathrm{Zn}$ (II) ion-binding properties; thus, they have received increased attention due to their capability to specifically inhibit CAs [42]. In fact, they form a complex in the enzyme active site with a tetrahedral geometry that is centered at the catalytic $\mathrm{Zn}$ (II) ion, with the $\mathrm{N}$ atom of the sulfonamide moiety coordinated to the bivalent metal $[4,36-38,43]$.

In order to investigate the inhibition profile of MpaCA and to compare results with that of other enzyme homologues, the interaction of 41 main sulfonamides and 1 sulfamate with the enzyme from $M$. pachydermatis was investigated in vitro. The molecular structure of these compounds is shown in Figure 4. The derivatives 1-24 and AAZ-EPA are either simple aromatic or heterocyclic sulfonamides, and are frequently used as building blocks to create novel potent and selective pharmaceuticals [43,44]. The series AAZ-EPA (see Table 1 for their identification) involves classical CA inhibitors (CAIs) used in clinics for managing and treating glaucoma, idiopathic intracranial hypertension, altitude sickness, congestive heart failure, epilepsy, and other diseases [4,36-38,43,45]. 
A<smiles>COc1cccc(N)c1</smiles><smiles>NOc1ccc(N)cc1</smiles><smiles>NOc1cccc(ON)c1</smiles>

1<smiles>COc1ccc(C)cc1</smiles><smiles>Cc1ccc(ON)cc1</smiles><smiles>NOc1ccc(N)cc1F</smiles><smiles>Nc1ccc(N)c(Cl)c1</smiles>

5<smiles>NOc1ccc(N)c(ON)c1</smiles>

10<smiles>Cc1ccc(ON)cc1</smiles>

4

8

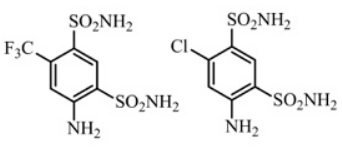

11<smiles>Cn1nc([Sn](N)=O)sc1=N</smiles>

13

14

$$
\begin{aligned}
& 15 n=0 \\
& 16 n=1
\end{aligned}
$$

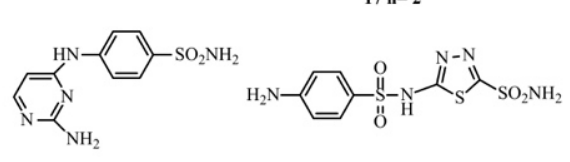

19
20
B<smiles></smiles>

AAZ

MZA

EAZ<smiles>NOc1cc([N+](N)=O)cc(Cl)c1Cl</smiles><smiles></smiles>

DCP

DZA

BRZ

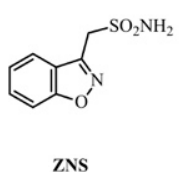

BZA<smiles>COc1ccc(S(N)(=O)=O)cc1C(=O)NCC1CCCN1C</smiles>

SLP

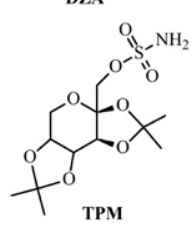

TPM

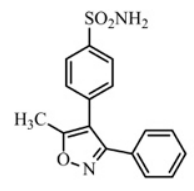

VLX

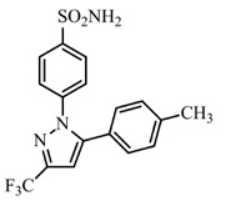

CLX

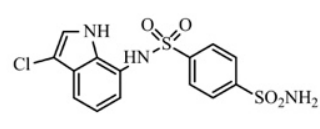

IND

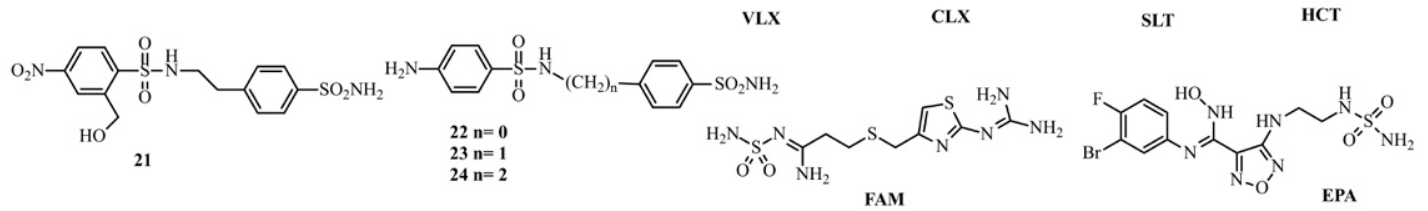

Figure 4. The structure of the compounds 1-24 (Panel A) and AAZ-EPA (Panel B) investigated as inhibitors of MpaCA.

Table 1. CAI clinically used drugs identified with their short and commercial name.

\begin{tabular}{cc}
\hline CAI & Commercial Name \\
\hline AAZ & Acetazolamide \\
MZA & Methazolamide \\
EZA & Ethoxzolamide \\
DZA & Dorzolamide \\
BRZ & Brinzolamide \\
BZA & Benzolamide \\
TPM & Topiramate \\
SLP & Sulpiride \\
IND & Indisulam E7070 \\
ZNS & Zonisamide \\
CLX & Celecoxib \\
VLX & Valdecoxib \\
SLT & Sulthiame \\
SAC & Saccharin \\
HCT & Hydrochlorothiazide \\
FAM & Famotidine \\
DCP & Dichlorophenamide \\
EPA & Epacadostat \\
\hline
\end{tabular}


Recently, we reported the inhibition profiles of sulfonamides against MreCA and MgCA [26-33]. Since these two fungal CAs have been proposed as new pharmacological targets for combatting fungal infection and showed a different inhibition pattern toward CAIs [26-33], we decided to explore the in vitro effect of the above-mentioned compounds on the activity of MpaCA. The data of the other two Malassezia enzymes (MreCA and $\mathrm{MgCA}$ ) are here provided for comparison purposes. The corresponding $\mathrm{K}_{\mathrm{I}}$ values are shown in Table 2.

Table 2. Inhibition profile of $\mathrm{MpaCA}, \mathrm{MreCA}$, and $\mathrm{MgCA}$ with respect to forty-one sulfonamide and one sulfamate derivatives.

\begin{tabular}{|c|c|c|c|}
\hline \multirow[b]{2}{*}{ Inhibitor } & \multicolumn{3}{|c|}{$\mathrm{K}_{\mathrm{I}}(\mu \mathrm{M}) *$} \\
\hline & MpaCA & ${ }^{\text {a }}$ MreCA & ${ }^{a} \mathrm{MgCA}$ \\
\hline 1 & 1.99 & 4.12 & 9.8 \\
\hline 2 & 3.07 & 4.62 & 0.24 \\
\hline 3 & 1.5 & $>10$ & 0.15 \\
\hline 4 & 1.09 & 4.04 & 6.74 \\
\hline 5 & 2.18 & $>10$ & 0.17 \\
\hline 6 & 1.34 & $>10$ & 0.07 \\
\hline 7 & 2.48 & 4.59 & 0.11 \\
\hline 8 & 1.68 & $>10$ & 0.12 \\
\hline 9 & 0.48 & $>10$ & 0.34 \\
\hline 10 & 2.01 & $>10$ & 0.54 \\
\hline 11 & 2.32 & 6.76 & 0.09 \\
\hline 12 & 2.74 & $>10$ & 0.09 \\
\hline 13 & 1.09 & $>10$ & $>10$ \\
\hline 14 & 0.58 & $>10$ & $>10$ \\
\hline 15 & 0.61 & $>10$ & 0.23 \\
\hline 16 & 1.06 & 6.51 & 0.10 \\
\hline 17 & 1.22 & $>10$ & 0.06 \\
\hline 18 & 1.56 & $>10$ & 0.06 \\
\hline 19 & 0.59 & 7.79 & $>10$ \\
\hline 20 & 0.61 & 0.91 & 0.23 \\
\hline 21 & 0.27 & 7.4 & 0.11 \\
\hline 22 & 1.37 & 3.74 & 0.09 \\
\hline 23 & 0.26 & $>10$ & $>10$ \\
\hline 24 & 1.27 & $>10$ & 2.56 \\
\hline AAZ & 0.62 & 0.1 & $>10$ \\
\hline MZA & 1.72 & 3.9 & $>10$ \\
\hline EZA & 2.46 & 3.79 & $>10$ \\
\hline DZA & 1.11 & 0.81 & $>10$ \\
\hline BRZ & 0.55 & 0.7 & $>10$ \\
\hline BZA & 0.12 & 7.15 & 0.48 \\
\hline TPM & 0.48 & 3.83 & 1.46 \\
\hline SLP & 1.19 & 4.85 & 0.32 \\
\hline IND & 4.82 & 0.87 . & n.d. \\
\hline ZNS & 2.42 & $>10$ & 7.65 \\
\hline CLX & 0.06 & 1.4 & $>10$ \\
\hline VLX & 0.63 & 0.77 & $>10$ \\
\hline SLT & 1.88 & 0.67 & n.d. \\
\hline SAC & 1.03 & 6.2 & n.d. \\
\hline HCT & 0.26 & 8.5 & n.d. \\
\hline FAM & 4.91 & $>10$ & n.d. \\
\hline DCP & 1.20 & 3.06 & 0.34 \\
\hline EPA & 0.63 & n.d. & n.d. \\
\hline
\end{tabular}

${ }^{*}$ Mean from three different assays as performed by stopped-flow experiments (errors were in the range of $\pm 5-10 \%$ of the reported values). ${ }^{\text {a }}$ From ref. [26]; n.d.: not detected. 
From the results shown in Table 2, the following conclusions can be drawn.

1. Only fifteen drugs inhibited MpaCA with inhibition constant $\left(\mathrm{K}_{\mathrm{Is}}\right)$ values less than $1.0 \mu \mathrm{M}$. Sulfonamide inhibitors of the series 1-24, such as 9, 14, 15, 19, 20, 21, 23, and clinically used sulfonamide drugs of the series AAZ-EPA, such as AAZ, BRZ, BZA, TMP, CLX, VLX, HCT, and EPA, are significant examples. All these inhibitors showed $\mathrm{K}_{\mathrm{I}}$ values in the range $0.06-0.62 \mu \mathrm{M}$ (Table 2 and Figure 5A). MreCA showed only seven "good inhibitors" (20, AAZ, DZA, BRZ, IND, VLX, and SLT) with $\mathrm{K}_{\mathrm{I}}$ values $<1.0 \mu \mathrm{M}$ (Table 2 and Figure $5 \mathrm{~B}$ ), while MgCA was well inhibited ( $\mathrm{K}_{\mathrm{I}}$ values $0.06-0.54 \mu \mathrm{M})$ by the following twenty compounds: $2,3,5,6,7,8,9,10,11,12,15,16$, 17, 18, 20, 21, 22, BZA, SLP and DCP (Table 2 and Figure 5C).

A

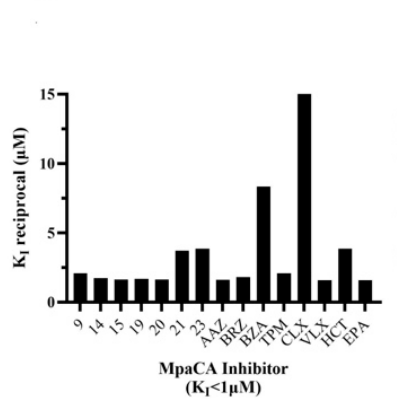

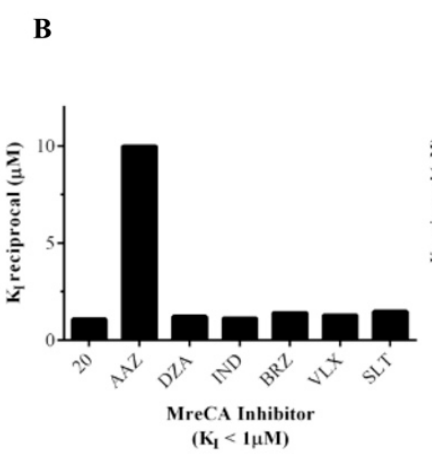

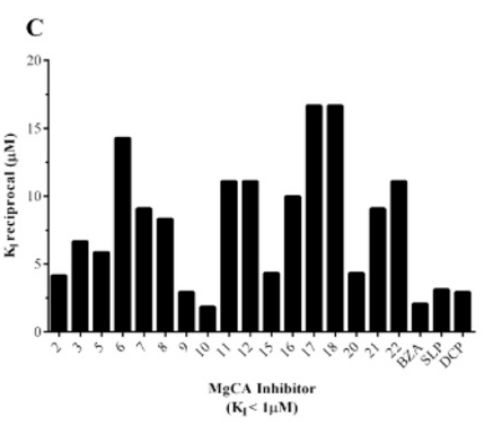

Figure 5. Graphical representation of the sulfonamide compounds exhibiting inhibitor activity with $\mathrm{K}_{\mathrm{I}}$ values $<1.0 \mu \mathrm{M}$ with respect to MpaCA (Panel A), MreCA (Panel B) and MgCA (Panel C). The $\mathrm{K}_{\mathrm{I}}$ values are reported as the reciprocal to have the highest column to the best enzyme inhibitor.

Interestingly, some good MpaCA inhibitors showed a moderate to limited inhibition activity on the other fungal homologous enzymes. For example, AAZ appeared as a promising inhibitor of $\mathrm{MpaCA}\left(\mathrm{K}_{\mathrm{I}}\right.$ value $\left.=0.62 \mu \mathrm{M}\right)$ and $\mathrm{MreCA}\left(\mathrm{K}_{\mathrm{I}}\right.$ value $\left.=0.1 \mu \mathrm{M}\right)$, but slightly inhibited MgCA $\left(\mathrm{K}_{\mathrm{I}}>10 \mu \mathrm{M}\right)$ (Table 2). On the other hand, several good sulfonamide inhibitors of $\mathrm{MgCA}$, with $\mathrm{K}_{\mathrm{I}}$ values $<1.0 \mu \mathrm{M}$, showed $\mathrm{K}_{\mathrm{I}}$ values in the range 1-10 $\mu \mathrm{M}$ when used against MpaCA, and were alos weak inhibitors of MreCA (Table 2), denoting how different the sulfonamide inhibition profiles were of the three fungal homologous $\beta$-CAs.

2. Many compounds of the series 1-24 and AAZ-EPA $(1,2,3,4,5,6,7,8,10,11,12$, 13, 16, 17, 18, 22, 24, MZA, EZA, DZA, SLP, IND, ZNS, SLT, SAC, FAM, and DCP) examined on MpaCA demonstrated a moderate inhibitory effect on this enzyme, with $\mathrm{K}_{\mathrm{I}}$ values in the range 1.06-4.91 $\mu \mathrm{M}$ (Table 2 and Figure 6A). A number of these small molecules, namely 1, 4, 13, 24, MZA, EZA, ZNS, FAM, and SAC, were also weak inhibitors of MreCA and $\mathrm{MgCA}$, showing $\mathrm{K}_{\mathrm{I}}$ values higher than $1.0 \mu \mathrm{M}$. Figure $6 \mathrm{~B}, \mathrm{C}$ provide a graphical representation of these findings, showing sulfonamide inhibitors with $1 \mu \mathrm{M}<\mathrm{K}_{\mathrm{I}} \mathrm{s}<10 \mu \mathrm{M}$ for these fungal enzymes.

3. As mentioned above, many of the chemicals reported in Table 2 were weak inhibitors of MreCA $(\mathrm{Ki}>10 \mu \mathrm{M})$ and were already demonstrated to be effective and moderate inhibitors of the human isoenzyme II (hCA II) [26], MpaCA and MgCA, respectively. As highlighted above, MreCA showed an inhibition pattern markedly different from those of the other two homologous enzymes MpaCA and MgCA (Table 2). 


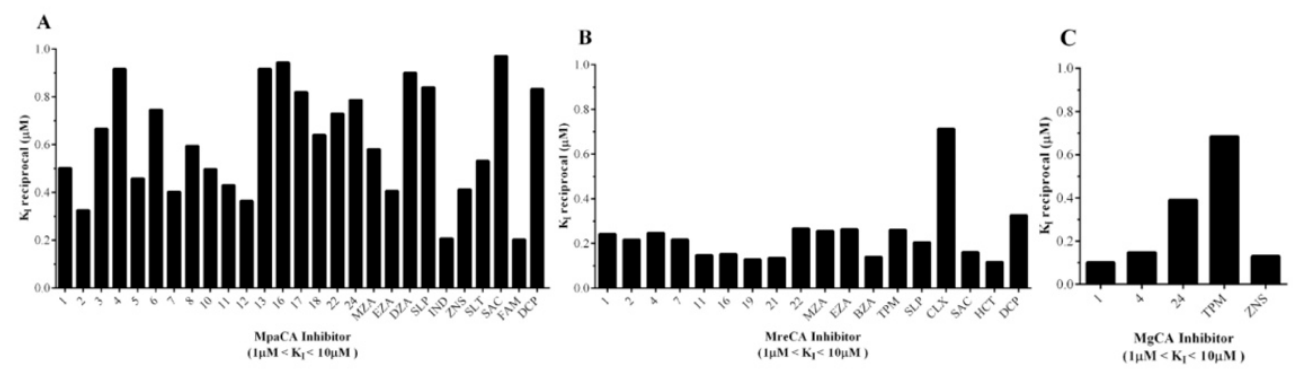

Figure 6. Graphical representation of the sulfonamide compounds exhibiting inhibitor activity with $\mathrm{K}_{\mathrm{I}}$ values in the range between 1 and $10 \mu \mathrm{M}$ with respect to MpaCA (Panel A), MreCA (Panel B), and MgCA (Panel C). The $\mathrm{K}_{\mathrm{I}}$ values are reported as the reciprocal to have the highest column to the best enzyme inhibitor.

\section{Materials and Methods}

\subsection{MpaCA Production: Synthetic Gene, Cloning, Heterologous Expression, and Purification}

The synthetic MpaCA gene was designed in our labs and produced by Life Technologies (Invitrogen, Carlsbad, CA, USA). Briefly, the MpaCA gene contained NdeI and XhoI restrictions sites at the $5^{\prime}$ - and $3^{\prime}$-ends, respectively; it was ligated into the expression vector pET100/D-TOPO (Invitrogen, Carlsbad, CA, USA) to form the expression vector pET100D-Topo/MpaCA, containing a nucleotide sequence encoding for a polypeptide with additional six histidines before the insertion point, for facilitating the purification of the resulting recombinant protein. To overexpress $M p a C A$, competent E. coli BL21 (DE3)pLysS (Agilent, Santa Clara, CA, USA) cells were transformed with pET100D-Topo/MpaCA, growing them in $1 \mathrm{~L}$ of $\mathrm{LB}$ broth at $37^{\circ} \mathrm{C}$. Isopropyl- $\beta$-D-thiogalactopyranoside (IPTG) was added to a final concentration of $1 \mathrm{mM}$, and $0.5 \mathrm{mM} \mathrm{ZnSO}_{4}$ was added after incubation for $30 \mathrm{~min}$ for uptake in the expressed protein. The incubation period continued for an additional $3 \mathrm{~h}$ at $37^{\circ} \mathrm{C}$. To verify the overexpression of $\mathrm{MpaCA}$, the resulting bacterial suspension was tested and analyzed on 12\% T SDS-PAGE, according to Laemmli [46]. At $3 \mathrm{~h}$ post-induction, the cellular extract was prepared by sonication at $4{ }^{\circ} \mathrm{C}$. Following centrifugation, the supernatant containing the overrepresented MpaCA was purified using a HIS-Select HF Nickel Affinity Gel (Sigma-Aldrich, St. Louis, MO, USA), which was equilibrated with a $0.02 \mathrm{M}$ phosphate buffer ( $\mathrm{pH} 8.0$ ) containing $0.01 \mathrm{M}$ imidazole and $0.5 \mathrm{M} \mathrm{KCl}$, at a flow rate of $1.0 \mathrm{~mL} / \mathrm{min}$. MpaCA was eluted from the column with $0.02 \mathrm{M}$ phosphate buffer ( $\mathrm{pH} 8.0$ ) containing $0.5 \mathrm{M} \mathrm{KCl}$ and $0.3 \mathrm{M}$ imidazole, at a flow rate of $1.0 \mathrm{~mL} / \mathrm{min}$ [34]. The protein concentration of the obtained active fractions was determined with a Bio-Rad protein assay based on the Bradford method [47]. The enzyme resulted at least 95\% pure. About $1.0 \mathrm{mg}$ of final recombinant enzyme was obtained from $1 \mathrm{~L}$ of bacterial culture.

\subsection{Enzyme Protonography}

For protonography, SDS-PAGE was performed as described by De Luca et al. [48]. Samples were mixed in a loading buffer without 2-mercaptoethanol, and they were not boiled to avoid protein denaturation. After electrophoresis, the gel was subject to protonography to detect the hydratase activity [48].

\subsection{Enzyme Assays}

An applied photophysics stopped-flow instrument was used for assaying the CAcatalyzed $\mathrm{CO}_{2}$ hydration activity [49]. Phenol red (at a concentration of $0.2 \mathrm{mM}$ ) was used as an indicator in a buffer containing $20 \mathrm{mM}$ Tris (pH 8.3), $20 \mathrm{mM} \mathrm{NaClO}_{4}$ (for maintaining a constant ionic strength), measuring the absorbance maximum of $557 \mathrm{~nm}$, and following the initial rate of the $\mathrm{CA}$-catalyzed $\mathrm{CO}_{2}$ hydration reactions for a period of 10-100 s. The $\mathrm{CO}_{2}$ concentrations values ranged from 1.7 to $17 \mathrm{mM}$ during the determination of the kinetic parameters. 


\subsection{Inhibition Assays}

At least six measurements of the original $5-10 \%$ reaction were used to assess the initial velocity for each inhibitor. The uncatalyzed rates were identically determined and detracted from the total observed rates. Stock inhibitor solutions $(10-100 \mathrm{mM})$ were prepared in distilled, deionized water, and dilutions up to $0.01 \mathrm{mM}$ were performed with the buffer test. Inhibitor and enzyme solutions were preincubated together for $15 \mathrm{~min}$ at room temperature prior to the assay, in order to allow the formation of the E-I complex or the eventual active site-mediated hydrolysis of the inhibitor. The inhibition constants, which represent the mean from at least three different determinations, were obtained by the non-linear least-squares methods using PRISM 6 and the Cheng-Prusoff equation, as reported earlier [50]. MgCA and MreCA were recombinant enzymes obtained inhouse. All salts/small molecules were of the highest purity available from Sigma-Aldrich (Milan, Italy).

\section{Conclusions}

Fungal MpaCA was generated as a soluble recombinant protein using E. coli cells as the host. SDS-PAGE, protonography, and the stopped-flow experiments showed that MpaCA has a molecular mass of about $30 \mathrm{kDa}$ and an excellent hydratase activity, converting the $\mathrm{CO}_{2}$ to bicarbonate and protons with a $\mathrm{k}_{\text {cat }}$ value of $3.8 \times 10^{5} \mathrm{~s}^{-1}$. By using the simple aromatic/heterocyclic compounds 1-24 and the therapeutically used drugs AAZEPA, the MpaCA sulfonamide inhibition profile was determined. Among the compounds belonging to both series, only 9, 14, 15, 19, 20, 21, 23, AAZ, BRZ, BZA, TMP, CLX, VLX, $\mathrm{HCT}$, and EPA inhibited MpaCA with $\mathrm{K}_{\mathrm{I}}$ values $<1.0 \mu \mathrm{M}$, highlighting these compounds as promising compounds to be further tested for future veterinary and medical applications. The comparative analysis of the sulfonamide inhibition profiles of $\mathrm{MpaCA}, \mathrm{MreCA}$, and $\mathrm{MgCA}$ highlighted that MpaCA exhibits an inhibitory pattern similar to MgCA, but which is radically different from that of its homolog MreCAs. Considering the sulfonamide inhibition pattern of the human isoforms I and II (hCAI and hCA II) previously determined by our group [26], the above-mentioned fungal enzymes showed significant inhibitory differences with those of the human counterparts.

The differences in the inhibitory effect of the sulfonamides on the three fungal enzymes can be explained considering the structural properties of each biocatalyst here studied. Sulfonamides form an enzyme-inhibitor complex with tetrahedral geometry centered at the $\mathrm{Zn}$ (II) ion also involving the $\mathrm{N}$ atom of the sulfonamide moiety. An extended network of hydrogen bonds involving amino acids of the enzyme also contributes to the inhibitor molecule anchoring to the metal ion. Besides, an interaction occurs between the aromatic/heterocycle portions of the inhibitor and the hydrophilic and hydrophobic residues present in the catalytic pocket of the enzyme $[4,36-38,43,51]$. Thus, it is reasonable to speculate that various residues present in the catalytic pocket of the different Malassezia enzymes may be responsible for the observed differences in the calculated $\mathrm{K}_{\mathrm{I}}$ values measured for the 42 compounds described in this study. Unfortunately, none of the three fungal enzymes were crystallized and, accordingly, no structural data were available for rationalizing the enzyme's behavior versus the investigated sulfonamides. However, these findings are encouraging because they show that, even though these CAs are very similar, there is a good chance for synthesizing inhibitors that can specifically inhibit CAs from the various fungi reported in this study as well as the human isozymes.

Author Contributions: Data curation, V.D.L.; A.A.; F.C.; S.S. and C.C.; Funding acquisition, F.C.; C.T.S. and C.C.; Investigation, V.D.L., A.A.; V.M.; C.A.; V.C. and C.C.; Supervision, C.T.S. and C.C.; Writing-original draft, C.C.; Writing-review and editing, C.T.S.; A.S. and C.C. All authors have read and agreed to the published version of the manuscript.

Funding: This research was funded by the Italian Ministry of University and Research, project FISR2019_04819 BacCAD (to C.T.S. and C.C.). Fabrizio Carta (F.C.) is grateful to "Fondazione Cassa di Risparmio di Firenze (Grant Number ECR2018.1001) for supporting this work. 
Institutional Review Board Statement: Not applicable.

Informed Consent Statement: Not applicable.

Acknowledgments: The authors are grateful to Valentina Brasiello and Giovanni Del Monaco for their technical assistance.

Conflicts of Interest: The authors declare no conflict of interest.

\section{References}

1. Cummins, E.P.; Selfridge, A.C.; Sporn, P.H.; Sznajder, J.I.; Taylor, C.T. Carbon dioxide-sensing in organisms and its implications for human disease. Cell. Mol. Life Sci. 2014, 71, 831-845. [CrossRef]

2. $\quad$ Endeward, V.; Musa-Aziz, R.; Cooper, G.J.; Chen, L.M.; Pelletier, M.F.; Virkki, L.V.; Supuran, C.T.; King, L.S.; Boron, W.F.; Gros, G. Evidence that aquaporin 1 is a major pathway for $\mathrm{CO} 2$ transport across the human erythrocyte membrane. FASEB J. 2006, 20, 1974-1981. [CrossRef]

3. Swenson, E.R. Does Aerobic Respiration Produce Carbon Dioxide or Hydrogen Ion and Bicarbonate? Anesthesiology 2018, 128, 873-879. [CrossRef]

4. Supuran, C.T.; Capasso, C. A Highlight on the Inhibition of Fungal Carbonic Anhydrases as Drug Targets for the Antifungal Armamentarium. Int. J. Mol. Sci. 2021, 22, 4324. [CrossRef]

5. Angiolella, L.; Carradori, S.; Maccallini, C.; Giusiano, G.; Supuran, C.T. Targeting Malassezia species for Novel Synthetic and Natural Antidandruff Agents. Curr. Med. Chem. 2017, 24, 2392-2412. [CrossRef] [PubMed]

6. Annunziato, G.; Angeli, A.; D’Alba, F.; Bruno, A.; Pieroni, M.; Vullo, D.; De Luca, V.; Capasso, C.; Supuran, C.T.; Costantino, G. Discovery of New Potential Anti-Infective Compounds Based on Carbonic Anhydrase Inhibitors by Rational Target-Focused Repurposing Approaches. ChemMedChem 2016, 11, 1904-1914. [CrossRef] [PubMed]

7. Ozensoy Guler, O.; Capasso, C.; Supuran, C.T. A magnificent enzyme superfamily: Carbonic anhydrases, their purification and characterization. J. Enzyme Inhib. Med. Chem. 2016, 31, 689-694. [CrossRef]

8. Del Prete, S.; Vullo, D.; De Luca, V.; Carginale, V.; Ferraroni, M.; Osman, S.M.; AlOthman, Z.; Supuran, C.T.; Capasso, C. Sulfonamide inhibition studies of the beta-carbonic anhydrase from the pathogenic bacterium Vibrio cholerae. Bioorg. Med. Chem. 2016, 24, 1115-1120. [CrossRef]

9. Del Prete, S.; De Luca, V.; De Simone, G.; Supuran, C.T.; Capasso, C. Cloning, expression and purification of the complete domain of the eta-carbonic anhydrase from Plasmodium falciparum. J. Enzyme Inhib. Med. Chem. 2016, 31, 54-59. [CrossRef]

10. Capasso, C.; Supuran, C.T. An Overview of the Carbonic Anhydrases from Two Pathogens of the Oral Cavity: Streptococcus mutans and Porphyromonas gingivalis. Curr. Top. Med. Chem. 2016, 16, 2359-2368. [CrossRef] [PubMed]

11. Capasso, C.; Supuran, C.T. An overview of the alpha-, beta- and gamma-carbonic anhydrases from Bacteria: Can bacterial carbonic anhydrases shed new light on evolution of bacteria? J. Enzyme Inhib. Med. Chem. 2015, 30, 325-332. [CrossRef]

12. Supuran, C.T.; Capasso, C. An Overview of the Bacterial Carbonic Anhydrases. Metabolites 2017, 7, 56. [CrossRef]

13. Ohkuni, K.; Hayashi, M.; Yamashita, I. Bicarbonate-mediated social communication stimulates meiosis and sporulation of Saccharomyces cerevisiae. Yeast 1998, 14, 623-631. [CrossRef]

14. D'Souza, C.A.; Heitman, J. Conserved cAMP signaling cascades regulate fungal development and virulence. FEMS Microbiol. Rev. 2001, 25, 349-364. [CrossRef] [PubMed]

15. Staniszewska, M. Virulence Factors in Candida species. Curr. Protein Pept. Sci. 2020, 21, 313-323. [CrossRef]

16. Mogensen, E.G.; Janbon, G.; Chaloupka, J.; Steegborn, C.; Fu, M.S.; Moyrand, F.; Klengel, T.; Pearson, D.S.; Geeves, M.A.; Buck, J.; et al. Cryptococcus neoformans senses CO2 through the carbonic anhydrase Can2 and the adenylyl cyclase Cac1. Eukaryot. Cell 2006, 5, 103-111. [CrossRef]

17. Schlicker, C.; Hall, R.A.; Vullo, D.; Middelhaufe, S.; Gertz, M.; Supuran, C.T.; Muhlschlegel, F.A.; Steegborn, C. Structure and inhibition of the CO2-sensing carbonic anhydrase Can2 from the pathogenic fungus Cryptococcus neoformans. J. Mol. Biol. 2009, 385, 1207-1220. [CrossRef] [PubMed]

18. Klengel, T.; Liang, W.J.; Chaloupka, J.; Ruoff, C.; Schroppel, K.; Naglik, J.R.; Eckert, S.E.; Mogensen, E.G.; Haynes, K.; Tuite, M.F.; et al. Fungal adenylyl cyclase integrates CO2 sensing with cAMP signaling and virulence. Curr. Biol. 2005, 15, 2021-2026. [CrossRef] [PubMed]

19. Chang, J.C.; Oude-Elferink, R.P. Role of the bicarbonate-responsive soluble adenylyl cyclase in pH sensing and metabolic regulation. Front. Physiol. 2014, 5, 42. [CrossRef]

20. Hewitson, K.S.; Vullo, D.; Scozzafava, A.; Mastrolorenzo, A.; Supuran, C.T. Molecular cloning, characterization, and inhibition studies of a beta-carbonic anhydrase from Malassezia globosa, a potential antidandruff target. J. Med. Chem. 2012, 55, 3513-3520. [CrossRef]

21. Rhimi, W.; Theelen, B.; Boekhout, T.; Otranto, D.; Cafarchia, C. Malassezia spp. Yeasts of Emerging Concern in Fungemia. Front. Cell. Infect. Microbiol. 2020, 10, 370. [CrossRef]

22. Guillot, J.; Bond, R. Malassezia Yeasts in Veterinary Dermatology: An Updated Overview. Front. Cell. Infect. Microbiol. 2020, 10, 79. [CrossRef] [PubMed]

23. Fan, Y.M.; Huang, W.M.; Li, S.F.; Wu, G.F.; Lai, K.; Chen, R.Y. Granulomatous skin infection caused by Malassezia pachydermatis in a dog owner. Arch. Dermatol. 2006, 142, 1181-1184. [CrossRef] [PubMed] 
24. Guillot, J.; Bond, R. Malassezia pachydermatis: A review. Med. Mycol. 1999, 37, 295-306. [CrossRef]

25. Del Prete, S.; Vullo, D.; Ghobril, C.; Hitce, J.; Clavaud, C.; Marat, X.; Capasso, C.; Supuran, C.T. Cloning, Purification, and Characterization of a beta-Carbonic Anhydrase from Malassezia restricta, an Opportunistic Pathogen Involved in Dandruff and Seborrheic Dermatitis. Int. J. Mol. Sci. 2019, 20, 2447. [CrossRef] [PubMed]

26. Del Prete, S.; Angeli, A.; Ghobril, C.; Hitce, J.; Clavaud, C.; Marat, X.; Supuran, C.T.; Capasso, C. Sulfonamide Inhibition Profile of the beta-Carbonic Anhydrase from Malassezia restricta, An Opportunistic Pathogen Triggering Scalp Conditions. Metabolites 2020, 10, 39. [CrossRef]

27. Del Prete, S.; Vullo, D.; Osman, S.M.; AlOthman, Z.; Capasso, C.; Supuran, C.T. Anion inhibition studies of the dandruff-producing fungus Malassezia globosa beta-carbonic anhydrase MgCA. Bioorg. Med. Chem. Lett. 2015, 25, 5194-5198. [CrossRef]

28. Entezari Heravi, Y.; Bua, S.; Nocentini, A.; Del Prete, S.; Saboury, A.A.; Sereshti, H.; Capasso, C.; Gratteri, P.; Supuran, C.T. Inhibition of Malassezia globosa carbonic anhydrase with phenols. Bioorg. Med. Chem. 2017, 25, 2577-2582. [CrossRef]

29. Nocentini, A.; Vullo, D.; Del Prete, S.; Osman, S.M.; Alasmary, F.A.S.; AlOthman, Z.; Capasso, C.; Carta, F.; Gratteri, P.; Supuran, C.T. Inhibition of the beta-carbonic anhydrase from the dandruff-producing fungus Malassezia globosa with monothiocarbamates. J. Enzyme Inhib. Med. Chem. 2017, 32, 1064-1070. [CrossRef]

30. Vullo, D.; Del Prete, S.; Nocentini, A.; Osman, S.M.; AlOthman, Z.; Capasso, C.; Bozdag, M.; Carta, F.; Gratteri, P.; Supuran, C.T. Dithiocarbamates effectively inhibit the beta-carbonic anhydrase from the dandruff-producing fungus Malassezia globosa. Bioorg. Med. Chem. 2017, 25, 1260-1265. [CrossRef]

31. Nocentini, A.; Bua, S.; Del Prete, S.; Heravi, Y.E.; Saboury, A.A.; Karioti, A.; Bilia, A.R.; Capasso, C.; Gratteri, P.; Supuran, C.T. Natural Polyphenols Selectively Inhibit beta-Carbonic Anhydrase from the Dandruff-Producing Fungus Malassezia globosa: Activity and Modeling Studies. ChemMedChem 2018, 13, 816-823. [CrossRef]

32. Bua, S.; Osman, S.M.; AlOthman, Z.; Supuran, C.T.; Nocentini, A. Benzenesulfonamides incorporating nitrogenous bases show effective inhibition of beta-carbonic anhydrases from the pathogenic fungi Cryptococcus neoformans, Candida glabrata and Malassezia globosa. Bioorg. Chem. 2019, 86, 39-43. [CrossRef]

33. Paloukopoulou, C.; Govari, S.; Soulioti, A.; Stefanis, I.; Angeli, A.; Matheeussen, A.; Capasso, C.; Cos, P.; Supuran, C.T.; Karioti, A. Phenols from Origanum dictamnus L. and Thymus vulgaris L. and their activity against Malassezia globosa carbonic anhydrase. Nat. Prod. Res. 2021, 35, 1-7. [CrossRef] [PubMed]

34. Del Prete, S.; De Luca, V.; Vullo, D.; Osman, S.M.; AlOthman, Z.; Carginale, V.; Supuran, C.T.; Capasso, C. A new procedure for the cloning, expression and purification of the beta-carbonic anhydrase from the pathogenic yeast Malassezia globosa, an anti-dandruff drug target. J. Enzyme Inhib. Med. Chem. 2016, 31, 1156-1161. [CrossRef] [PubMed]

35. Kolaczek, A.; Fusiarz, I.; Lawecka, J.; Branowska, D. Biological activity and synthesis of sulfonamide derivatives: A brief review. Chemik 2014, 68, 625-628.

36. Supuran, C.T.; Capasso, C. Antibacterial carbonic anhydrase inhibitors: An update on the recent literature. Expert Opin. Ther. Pat. 2020, 30, 963-982. [CrossRef]

37. Supuran, C.T. Emerging role of carbonic anhydrase inhibitors. Clin. Sci. 2021, 135, 1233-1249. [CrossRef]

38. Angeli, A.; Carta, F.; Nocentini, A.; Winum, J.Y.; Zalubovskis, R.; Onnis, V.; Eldehna, W.M.; Capasso, C.; Carradori, S.; Donald, W.A.; et al. Response to Perspectives on the Classical Enzyme Carbonic Anhydrase and the Search for Inhibitors. Biophys. J. 2021, 120, 178-181. [CrossRef]

39. Ponka, D. Approach to managing patients with sulfa allergy-Use of antibiotic and nonantibiotic sulfonamides. Can. Fam. Physician 2006, 52, 1434-1438.

40. Keilin, D.; Mann, T. Carbonic anhydrase. Purification and nature of the enzyme. Biochem. J. 1940, 34, 1163-1176. [CrossRef] [PubMed]

41. Krebs, H.A. Inhibition of carbonic anhydrase by sulphonamides. Biochem. J. 1948, 43, 525-528. [CrossRef]

42. Shaldam, M.; Eldehna, W.M.; Nocentini, A.; Elsayed, Z.M.; Ibrahim, T.M.; Salem, R.; El-Domany, R.A.; Capasso, C.; Abdel-Aziz, H.A.; Supuran, C.T. Development of novel benzofuran-based SLC-0111 analogs as selective cancer-associated carbonic anhydrase isoform IX inhibitors. Eur. J. Med. Chem. 2021, 216, 113283. [CrossRef] [PubMed]

43. Capasso, C.; Supuran, C.T. An Overview of the Selectivity and Efficiency of the Bacterial Carbonic Anhydrase Inhibitors. Curr. Med. Chem. 2015, 22, 2130-2139. [CrossRef]

44. Angeli, A.; Kartsev, V.; Petrou, A.; Pinteala, M.; Vydzhak, R.M.; Panchishin, S.Y.; Brovarets, V.; De Luca, V.; Capasso, C.; Geronikaki, A.; et al. New Sulfanilamide Derivatives Incorporating Heterocyclic Carboxamide Moieties as Carbonic Anhydrase Inhibitors. Pharmaceuticals 2021, 14, 828. [CrossRef] [PubMed]

45. Vullo, D.; Leewattanapasuk, W.; Muhlschlegel, F.A.; Mastrolorenzo, A.; Capasso, C.; Supuran, C.T. Carbonic anhydrase inhibitors: Inhibition of the beta-class enzyme from the pathogenic yeast Candida glabrata with sulfonamides, sulfamates and sulfamides. Bioorg. Med. Chem. Lett. 2013, 23, 2647-2652. [CrossRef]

46. Laemmli, U.K. Cleavage of structural proteins during the assembly of the head of bacteriophage T4. Nature 1970, 227, 680-685. [CrossRef]

47. Bradford, M.M. A rapid and sensitive method for the quantitation of microgram quantities of protein utilizing the principle of protein-dye binding. Anal. Biochem. 1976, 72, 248-254. [CrossRef]

48. De Luca, V.; Del Prete, S.; Supuran, C.T.; Capasso, C. Protonography, a new technique for the analysis of carbonic anhydrase activity. J. Enzyme Inhib. Med. Chem. 2015, 30, 277-282. [CrossRef] [PubMed] 
49. Khalifah, R.G. The carbon dioxide hydration activity of carbonic anhydrase. I. Stop-flow kinetic studies on the native human isoenzymes B and C. J. Biol. Chem. 1971, 246, 2561-2573. [CrossRef]

50. Carta, F.; Temperini, C.; Innocenti, A.; Scozzafava, A.; Kaila, K.; Supuran, C.T. Polyamines inhibit carbonic anhydrases by anchoring to the zinc-coordinated water molecule. J. Med. Chem. 2010, 53, 5511-5522. [CrossRef]

51. Nocentini, A.; Angeli, A.; Carta, F.; Winum, J.Y.; Zalubovskis, R.; Carradori, S.; Capasso, C.; Donald, W.A.; Supuran, C.T. Reconsidering anion inhibitors in the general context of drug design studies of modulators of activity of the classical enzyme carbonic anhydrase. J. Enzyme Inhib. Med. Chem. 2021, 36, 561-580. [CrossRef] 